\title{
Profil Keterampilan Proses Sains Mahasiswa Pendidikan Guru Sekolah Dasar (PGSD) pada Mata Kuliah Konsep Biologi
}

\author{
Profile of Science Process Skill Elementary School College Students \\ on Biology Concept Course
}

\author{
Tisrin Maulina Dewi ${ }^{1 *}$ dan Muhiri ${ }^{2}$ \\ ${ }^{1}$ Prodi PGSD FKIP Universitas Karimun, Propinsi Kepulauan Riau; ${ }^{2}$ Prodi Penjaskesrek FKIP \\ Universitas Karimun, Propinsi Kepulauan Riau. Corespondent email: tisrinmaulinadewi@ gmail.com
}

Received: 24 July 2020 | Accepted: 15 Desember 2020 | Published: 30 Desember 2020

\begin{abstract}
Abstrak. Penelitian ini bertujuan untuk mendeskripsikan kemampuan Keterampilan Proses Sains (KPS) mahasiswa Program Studi Program Studi Pendidikan Guru Sekolah Dasar (PGSD) pada mata kuliah konsep biologi SD. Penelitian ini menggunakan metode deskriptif dengan pendekatan kualitatif. Subjek dalam penelitian ini adalah mahasiswa semester 6 Prodi PGSD Universitas Karimun berjumlah 25 orang mahasiswa dengan teknik pengambilan sampel yang dipilih secara Purposive Random Sampling. Data pada penelitian ini diperoleh melalui instrumen tes keterampilan proses sains mahasiswa dan kuisioner. Hasil penelitian menunjukkan bahwa keterampilan proses sains mahasiswa masih sangat rendah dengan nilai 13,8. Faktor yang mempengaruhi keterampilan proses sains terhadap proses pembelajaran memperoleh nilai $72,83 \%$ dengan kategori tinggi. Hal ini menunjukkan bahwa profil keterampilan proses sains mahasiswa PGSD masih rendah dan harus ditingkatkan.

Kata Kunci : Keterampilan Proses Sains, Mahasiswa PGSD, Biologi

Abstract. This study aims to describe the ability of Science Process Skills (KPS) students of the Elementary School Teacher Education Study Program (PGSD) in the Elementary School Biology concept course. This study uses a descriptive method with a qualitative approach. The subjects in this study were 25 students in the 6th semester of PGSD Study Program with the sampling technique selected by purposive random sampling. The data in this study were obtained through the students' science process skills test instruments and questionnaires. The results showed that students' science process skills were still very low with a value of 13.8. The factors that affect science process skills on the learning process score $72.83 \%$ in the high category. This shows that the profile of the science process skills of PGSD students is still low and must be improved.

Keywords : Science Process Skills, Elementary School Teacher Education Students (PGSD), Biology
\end{abstract}

\section{PENDAHULUAN}

Pendidikan adalah salah satu upaya untuk mendidik generasi bangsa agar memiliki kecakapan hidup dan pengetahuan agar siap bersaing di dalam kehidupan bermasyarakat. Menurut Widodo (2015) pendidikan yang bermutu adalah pendidikan yang mampu menggali dan mengembangkan potensi-potensi positif yang terdapat dalam diri siswa. Paradigma pendidikan yang telah bergeser dari behavioristik ke konstruktivitik menuntut para pendidik untuk menggunakan model pembelajaran yang membuat siswa aktif sehingga bisa mengembangkan potensi-potensi yang ada pada diri siswa .

Sains berkaitan dengan cara mencari tahu tentang alam secara sistematis, penguasaan kumpulan pengetahuan yang berupa fakta-fakta, konsep-konsep atau prinsip-prinsip serta merupakan suatu proses penemuan (Haristy, 2012). Ilmu Pengetahuan Alam (IPA) berhubungan dengan cara untuk mencari tahu tentang alam secara sistematis, sehingga IPA bukan hanya 
tentang pengetahuan yang berkaitan dengan fakta, prinsip dan konsep saja tetapi tentang suatu proses penemuan (Wahyuni, 2013). Hal ini berarti di dalam pembelajaran sains tidak hanya memuat teori saja, melainkan melibatkan aktivitas siswa untuk memecahkan masalah yang berkaitan dengan pembelajaran sehingga mampu membentuk keterampilan yang dapat diaplikasikan dalam kehidupan nyata. Keterampilan tersebut biasa dikenal dengan keerampilan proses yang merupakan bagian penting dalam sains. Keterampilan proses sains inilah yang selama ini tidak selalu menjadi perhatian dosen ketika membelajarkan pembelajaran sains.

Keterampilan proses sains merupakan kemampuan mengolah perilaku dan pemikiran ilmiah yang berfungsi untuk mengembangkan pemahaman konsep ilmiah yang akan menjadi penunjang kemampuan-kemampuan berikutnya (Amalia et al., 2016). Hal ini menunjukkan bahwa dengan keterampilan proses sains, siswa dapat mempelajari sains sesuai dengan yang para ahli sains lakukan, yaitu melalui pengamatan, klasifikasi, inferensi, merumuskan hipotesis dan melakukan eksperimen.

Keterampilan proses sains melibatkan berbagai macam keterampilan yaitu keterampilan kognitif, manual serta sosial. Keterampilan kognitif dilibatkan karena ada keterampilan berpikir di dalam keterampilan proses tersebut. Keterlibatan keterampilan manual dalam keterampilan proses yaitu pada saat penggunaan alat dan bahan, proses pengukuran, penyusunan atau perakitan alat. Keterampilan mencakup kemampuan mengendalikan diri, adaptasi, toleransi dan komunikasi serta partisipasi selama proses pembelajaran (Ulum, 2018).

Pendidikan IPA di sekolah dasar merupakan poses penguasaan konsep dan manfaat sains dalam kehidupan sehari-hari, serta pondasi bagi pendidikan selanjutnya, sehingga proses awal ini harus benar-benar kuat. IPA di sekolah dasar merupakan tahap awal untuk memberikan bekal kepada siswa agar mampu berfikir kritis, kreatif, logis dan berinisiatif dalam menghadapi tantangan di masyarakat.

Konsep-konsep dasar IPA Biologi harus dikuasai oleh guru, agar para siswa SD mempunyai kemampuan yang lebih baik dalam mempelajari IPA. Guru yang mengajar IPA di SD harus mempunyai pengetahuan IPA yang memadai terutama mengenai konsep-konsep dasar Biologi. Peranan guru di sekolah sangat menentukan hasil belajar siswa karena gurulah yang paling sering berinteraksi dengan siswanya. Peran guru tidak hanya berkewajiban menanamkan konsep dan proses dalam pembelajaran, tetapi juga menanamkan nilai sikap kepada siswa. Peranan guru yang paling penting adalah menjadikan guru sebagai salah satu komponen terpenting dalam menentukan keberhasilan pembelajaran. Menurut Sagala (2013), menyatakan bahwa guru bertugas merencanakan dan melaksanakan proses pembelajaran, menilai hasil pembelajaran, melakukan bimbingan dan latihan, melakukan penelitian dan pengkajian serta membuka komunikasi dengan masyarakat.

Penelitian ini bertujuan untuk mendeskripsikan kemampuan Keterampilan Proses Sains (KPS) mahasiswa Program Studi Program Studi Pendidikan Guru Sekolah Dasar (PGSD) pada mata kuliah konsep Biologi SD.

\section{METODE PENELITIAN}

Penelitian ini dilaksanakan di Fakultas Keguruan dan Ilmu Pendidikan Universitas Karimun Jalan Canggai Puteri Kecamatan Tebing Kabupaten Karimun, dengan waktu penelitian mulai Maret sampai Mei 2018. Penelitian ini merupakan penelitian deskriptif yang bertujuan untuk memberikan atau menjabarkan suatu keadaan tentang keterampilan proses sains 
mahasiswa. Populasi dalam penelitian ini adalah seluruh mahasiswa Prodi Pendidikan Guru Sekolah Dasar (PGSD) dengan jumlah 89 mahasiswa dan sampel dalam penelitian ini adalah mahasiswa semester 6 Prodi PGSD berjumlah 25 orang mahasiswa. Teknik pengambilan sampel yang dipilih secara Purposive Random Sampling yaitu teknik pengambilan sampel yang digunakan dengan adanya tujuan khusus, yaitu karena mahasiswa sudah menerima mata kuliah konsep biologi SD 1 dan konsep biologi SD 2 dan akan melaksanakan praktik program pengalaman lapangan di sekolah.

Instrumen penelitian yang digunakan dalam penelitian ini adalah tes keterampilan proses sains mahasiswa dan kuisioner keterampilan proses sains. Soal tes keterampilan proses sains berjumlah 20 butir pertanyaan dalam bentuk pilihan ganda yang dibuat berdasarkan sepuluh indikator keterampilan proses sains. Secara rinci bisa dilihat pada Tabel 1.

Tabel 1. Klasifikasi soal keterampilan proses sains berdasarkan indikator

\begin{tabular}{clc}
\hline No & \multicolumn{1}{c}{ Indikator Keterampilan Proses Sains } & No Soal \\
\hline 1 & Mengamati & 1,2 \\
2 & Mengelompokkan / Klasifikasi & 3,9 \\
3 & Memprediksi & 10 \\
4 & Mengajukan Pertanyaan & 14 \\
5 & Merumuskan Hipotesis & 4,11 \\
6 & Merencanakan Percobaan & 5,12 \\
7 & Menggunakan Alat / Bahan & 6 \\
8 & Menerapkan Konsep & 7 \\
9 & Menafsirkan & 15 \\
10 & Berkomunikasi & 8,13 \\
\hline
\end{tabular}

Selanjutnya untuk mengetahui kemampuan keterampilan proses sains mahasiswa dihitung menggunakan rumus (Purwanto, 2013):

$$
S=\frac{R}{N} X 100
$$

Dimana, $\mathrm{S}=$ Kemampuan keterampilan proses sains; $\mathrm{R}=$ Skor yang diperoleh dari jawaban yang benar; $\mathrm{N}=$ Jumlah skor maksimum dari tes.

Dari hasil perhitungan menggunakan rumus di atas akan menghasilkan angka. Perolehan skor tersebut selanjutnya dimaknai dengan kalimat bersifat kualitatif, sesuai dengan Tabel 2.

Tabel 2. Kriteria penilaian kemampuan keterampilan proses sains mahasiswa

\begin{tabular}{lll}
\hline No & Interval & Kriteria \\
\hline 1 & $86 \leq X<100$ & Sangat Tinggi \\
2 & $76 \leq X<85$ & Tinggi \\
3 & $60 \leq X<75$ & Sedang \\
4 & $55 \leq X<59$ & Rendah \\
5 & $\leq 54$ & Sangat Rendah \\
\hline
\end{tabular}

Adapun kuisioner yang digunakan dalam penelitian ini adalah kuisioner tertutup yaitu untuk mengetahui ada tidaknya keterkaitan antara kebiasaan belajar dan proses pembelajaran. Lembar kuosioner terdiri dari lima belas pertanyaan yang terdiri dari empat indikator yakni : mengetahui hubungan kebiasaan belajar dengan keterampilan proses sains mahasiswa, mengetahui hubungan ketersediaan fasilitas perguruan tinggi dengan keterampilan proses sains 
mahasiswa, mengetahui hubungan pembelajaran IPA biologi yang berlangsung di kelas dengan keterampilan proses sains mahasiswa dan mengetahui hubungan pembelajaran IPA yang berlangsung di luar perguruan tinggi dengan keterampilan proses sains mahasiswa. Hasil perolehan kuisioner mahasiswa dianalisis dengan rumus sebagai berikut:

$$
P R S=\frac{A}{B} x 100 \%
$$

Dimana, PRS = Persentase kemampuan keterampilan proses sains; A= Jumlah skor per kategori; $\mathrm{N}=$ Jumlah skor total.

Selanjutnya presentase faktor-faktor yang mempengaruhi keterampilan proses sains mahasiswa dikelompokkan kedalam kriteria sebagai berikut Tabel 3.

Tabel 3. Kriteria presentase penilaian faktor yang mempengaruhi keterampilan proses sains mahasiswa (Sugiyono, 2015).

\begin{tabular}{ll}
\hline Interval Persentase & Kriteria \\
\hline $81 \% \leq X<100 \%$ & Sangat Tinggi \\
$61 \% \leq X<80 \%$ & Tinggi \\
$41 \% \leq X<60 \%$ & Cukup \\
$21 \% \leq X<40 \%$ & Rendah \\
$0 \% \leq X<20 \%$ & Sangat Rendah \\
\hline
\end{tabular}

\section{HASIL DAN PEMBAHASAN}

Pada penelitian ini, data penelitian diperoleh dari hasil jawaban penilaian keterampilan proses sains mahasiswa dan kuosioner yang diberikan kepada mahasiswa. Penilaian keterampilan proses sains dalam penelitian ini meliputi pengetahuan yang berkenaan dengan konsep keterampilan proses sains (KPS) dan penggunaan KPS yaitu seberapa besar pengetahuan konsep KPS mahasiswa yang diuraikan melalui pertanyaan-pertanyaan yang sesuai dengan indikator KPS meliputi: mengamati, mengelompokkan (klasifikasi), memprediksi, mengajukan pertanyaan, merumuskan hipotesis, merencanakan percobaan, menggunakan alat dan bahan, menerapkan konsep, menafsirkan dan berkomunikasi. Skor penilaian keterampilan proses sains disajikan pada Gambar 1.

Nilai rata-rata penguasaan KPS responden pada keseluruhan indikator berada pada tingkat yang tergolong sangat rendah yaitu sebesar 13,8, terutama untuk indikator memprediksi, mengajukan pertanyaan, merumuskan hipotesis serta menggunakan alat dan bahan tergolong sangat rendah yaitu bernilai 0 karena tidak adanya satupun responden yang menjawab benar. Diikuti dengan indikator merencanakan percobaan bernilai 6 dengan kategori sangat rendah, menerapkan konsep bernilai 8 dengan kategori sangat rendah, berkomunikasi bernilai 16 memiliki kategori sangat rendah, menafsirkan bernilai 24 dengan kategori sangat rendah, mengelompokkan / mengklasifikasikan bernilai 36 dengan kategori sangat rendah dan indikator mengamati bernilai 48 memiliki kategori sangat rendah dalam penguasaan terhadap keterampilan proses sains.

Dari kesepuluh indikator KPS yang digunakan, untuk indikator mengamati memiliki nilai 48 dengn kategori sangat rendah. Mengamati atau observasi biasa dikatakan dengan pengamatan langsung yang mana mahasiswa melakukan kegiatan pengamatan secara langsung menggunakan panca inderanya. Untuk indikator yang memperoleh nilai yang sangat rendah yaitu bernilai 0 antara lain indikator memprediksi, mengajukan pertanyaan, merumuskan hipotesis dan menggunakan alat dan bahan. 


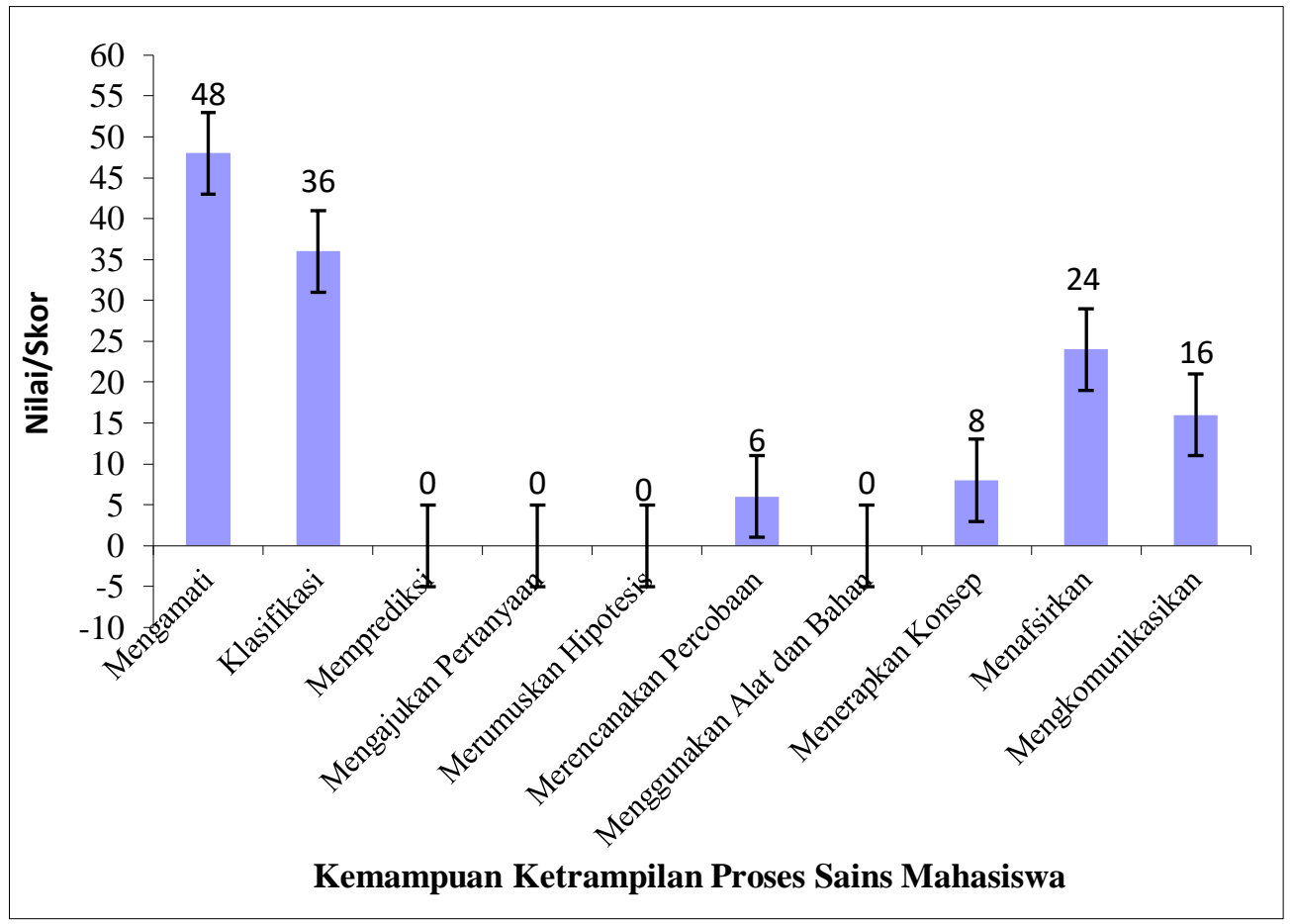

Gambar 1. Skor penilaian keterampilan proses sains mahasiswa

Indikator keterampilan memprediksi mendapat nilai 0 dengan kategori sangat rendah dikarenakan dalam memprediksi mahasiswa belum memahami data yang disajikan dengan baik, sehingga prediksi yang dilakukan belum akurat. Menurut Rustaman (2003), prediksi merupakan keterampilan penting dalam pembelajaran IPA dan belajar biologi, karena sehubungan dengan IPA yang didasarkan pada asumsi keyakinan tentang alam. Untuk indikator mengajukan pertanyaan juga memiliki nilai yang sangat rendah yaitu 0 , hal ini dikarenakan mahasiswa belum paham sehingga lebih memili untuk diam daripada bertanya. Menurut Trianto (2012) yang menyatakan bahwa pertanyaan yang diajukan dikatakan baik jika dalam pengkomunikasian berjalan dengan baik, komunikasi dikatakan baik jika pemaparan pengamatan atau dengan menggunakan bahasa dan kata yang sesuai.

Pada indikator mengajukan hipotesis memperoleh nilai yang sangat rendah yaitu 0 , hal ini dikarenakan mahasiswa masih belum mengerti tentang perumusan hipotesis berdasarkan pengamatan. Karena hipotesis itu merupakan dugaan sementara pada masalah yang ada dan perlu pembuktian berdasarkan data yang telah dianalisis (Sanjaya, 2013). Indikator menggunakan alat dan bahan memperoleh nilai 0 karena kondisi laboratorium IPA yang masih belum lengap dan memadai di Kampus Universitas Karimun, hal ini yang menyebabkan mahasiswa banyak yang tidak bisa menggunakan alat dan bahan. Padahal dalam pembelajaran IPA seperti biologi ada kegiatan praktikum yang membutuhkan ketersediaan sarana dan prasarana yang lengkap yang nantinya bisa menunjang pelaksanaan praktikum dan mengembangkan keterampilan proses sains mahasiswa (Lestari, 2017).

Keterampilan proses sains merupakan keterampilan yang sangat penting untuk dimiliki oleh mahasiswa, karena keterampilan ini merupakan keterampilan dasar untuk melakukan suatu kerja ilmiah. Pada pembelajaran IPA khususnya biologi, mahasiswa harus mampu mengembangkan keterampilan proses ini. Hal ini sesuai dengan hakikat dari sains yang 
menyatakan bahwa cara memperoleh sains itu adalah dengan melakukan kerja ilmiah melalui proses eksperimen yang membutuhkan keterampilan proses sains (Putri dan Erda, 2018). Keterampilan proses sains sangat penting untuk dimiliki oleh peserta didik sebagai bekal untuk menggunakan metode ilmiah dalam mengembangkan sains untuk memperoleh pengetahuan baru atau pengetahuan yang dimiliki (Maradona, 2013). Jika mahasiswa memiliki keterampilan proses sains yang baik, maka dapat membantu mengembangkan ilmu pengetahuannya dan bisa lebih memahami fakta dan konsep ilmu pengetahuannya dengan baik (Dewi, 2019).

Salah satu cara agar dapat meningkatkan keterampilan proses sains mahasiswa yaitu dengan mengembangkan suatu perangkat pembelajaran yaitu dengan menggunakan model pembelajaran berbasis masalah. Karena dengan pembelajaran berbasis masalah ini ditambahkan dengan bekal pengetahuan awal dapat memberikan kesempatan kepada mahasiswa untuk lebih aktif dan termotivasi mengembangkan kemampuan yang dimiliki untuk menemukan konsep aupun teori yang sedang dipelajari (Hikmawati et al., 2017). Selain itu, keterampilan proses sains juga perlu diintegrasikan kedalam pembelajaran, agar mahasiswa mampu menyelesaikan masalah dengan konsep-konsep sains dan memanfaatkan teknologi yang ada (Utama et al., 2019).

Selanjutnya untuk faktor yang mempengaruhi keterampilan proses sains ini dilakukan dengan memberikan kusioner kepada mahasiswa yang terdiri dari 15 pernyataan. Data hasil kuosioner faktor yang mempengaruhi keterampilan proses sains ini disajikan pada Tabel 4. Tabel 4. Rekapitulasi skor hasil kuosioner faktor yang mempengaruhi keterampilan proses sains

\begin{tabular}{clc}
\hline No & \multicolumn{1}{c}{ Indikator } & Skor (\%) \\
\hline 1 & Hubungan kebiasaan belajar & $86 \%$ \\
2 & Hubungan ketersediaan fasilitas perguruan tinggi & $57 \%$ \\
3 & $\begin{array}{l}\text { Hubungan pembelajaran IPA biologi yang } \\
\text { berlangsung di kelas }\end{array}$ & $81,3 \%$ \\
4 & $\begin{array}{l}\text { Hubungan pembelajaran IPA yang berlangsung di } \\
\text { luar perguruan tinggi }\end{array}$ & $67 \%$ \\
\hline & Rerata & $72,83 \%$ \\
\hline
\end{tabular}

Dari Tabel 4 diperoleh rata-rata hasil kuisioner tentang faktor-faktor yang mempengaruhi keterampilan proses sains yaitu rata-rata $72,83 \%$ dengan kategori tinggi. Indikator yang memiliki nilai tertinggi yaitu $86 \%$ dengan kategori sangat tinggi pengaruh untuk indikator mengetahui hubungan kebiasaan belajar dengan keterampilan proses sains mahasiswa. Untuk indikator mengetahui hubungan pembelajaran IPA biologi yang berlangsung di kelas dengan keterampilan proses sains mahasiswa memperoleh nilai $81,3 \%$ dengan kategori sangat tinggi sedangkan untuk indikator mengetahui hubungan pembelajaran IPA yang berlangsung di luar perguruan tinggi diperoleh nilai $67 \%$ dengan kategori tinggi.

Untuk indikator mengetahui hubungan ketersediaan fasilitas perguruan tinggi dengan keterampilan proses sains mahasiswa diperoleh nilai 57\% dengan kategori penilaian cukup mempengaruhi. Hal ini dikarenakan masih minimnya ketersediaan fasilitas yang dimiliki oleh perguruan tinggi. Ketersediaan fasilitas perguruan tinggi dalam mata kuliah konsep biologi SD berkaitan dengan ketersediaan alat dan bahan pada laboratorium IPA. Menurut Kustijono et al., (2018) menyatakan bahwa kegiatan eksperimen sangat diperlukan untuk melatih siswa untuk melakukan penyelidikan seperti yang direncanakan, sistematis dan dapat mengembangkan keterampilan proses sains. 


\section{KESIMPULAN}

Hasil penelitian menunjukkan bahwa rata-rata secara keseluruhan tingkat kemampuan keterampilan proses sains mahasiswa dengan nilai 13,8 yang termasuk pada kategori sangat rendah untuk sepuluh indikator yaitu mengamati, mengelompokkan (klasifikasi), memprediksi, mengajukan pertanyaan, merumuskan hipotesis, merencanakan percobaan, menggunakan alat dan bahan, menerapkan konsep, menafsirkan dan berkomunikasi. Faktor yang mempengaruhi keterampilan proses sains antara lain kebiasaan belajar, ketersediaan fasilitas perguruan tinggi, pembelajaran IPA biologi yang berlangsung di dalam kelas, dan pembelajaran IPA biologi yang berlangsung di luar perguruan tinggi dengan nilai rata-rata 72,83\% dengan kategori tinggi.

\section{REFERENSI}

Amalia, Y.F., Zainuddin, Z., dan Misbah, M. 2016. Pengembangan Bahan Ajar IPA Fisika Berorientasi Keterampilan Generik Sains Menggunakan Model Pembelajaran Inquiri Terbimbing di SMP Negeri 13 Banjarmasin. Berkala Ilmiah Pendidikan Fisika, 4(3): 183191.

Dewi, T.M. 2019. Pengembangan Buku Penuntun Praktikum IPA SD Berbasis Keterampilan Proses Sains pada Mata Kuliah Praktikum IPA SD untuk Mahasiswa Pendidikan Guru Sekolah Dasar (PGSD). Simbiosa, 8(1):28-36.

Haristy, D.R. 2012. Pembelajaran Berbasis Literasi Saintifik pada Materi Larutan Elektrolit dan Non Elektrolit di SMA Negeri 1 Pontianak. (Skripsi). Program Studi Pendidikan Kimia FKIP Universitas Tanjungpura Pontianak.

Hikmawati, N., Sutrio dan Hikmawati. 2017. Pengaruh Model Pembelajaran Berbasis Masalah dengan Pengetahuan Awal terhadap Keterampilan Proses Sains Peserta Didik SMA. Jurnal Pendidikan Fisika dan Teknologi, 3(1): 92-100.

Kustijono, R., Jatmiko, B., dan Ibrahim, M. 2018. The Effect of Scientific Attitudes Toward Scince Proccess Skills in Basic Physics Practicum by Using Peer Model. International Journal of Geomate. 15(50): 82-87.

Lestari, M.Y. 2017. Analisis Keterampilan Proses Sains pada Pelaksanaan Praktikum Fisika Dasar 1 terhadap Mahasiswa Pendidikan Fisika UIN Raden Intan Lampung. (Skripsi). Program Studi Pendidikan Fisika FKIP. UIN Raden Intan. Lampung.

Maradona. 2013. Analisis Keterampilan Proses Sains Siswa Kelas XI IPA SMA Islam Samarinda pada Pokok Bahasan Hidrolisis Melalui Metode Eksperimen. Prosiding Seminar Nasional Kimia (2013). Program Studi Kimia, Fakultas Matematika dan Ilmu Pengetahuan Alam, Universitas Mulawarman. Hlm 62-70.

Putri, A.N., dan Erda, M. 2018. Analisis Keterampilan Proses Sains Awal Mahasiswa pada Mata Kuliah Biologi Umum. Jurnal Pedagogi Hayati, 2(2):1-4.

Purwanto, M.N. 2013. Prinsip-Prinsip dan Teknik Evaluasi Pengajaran. PT. Remaja Rosdakarya. Jakarta. 166 hlm.

Rustaman, N. 2003. Peranan Pertanyaan Produktif dalam Pengembangan KPS dan LKS. Bahan Seminar dan Lokakarya Bagi Guru-Guru SLTP dan SMU. FPMIPA UPI. Bandung.

Sagala, S. 2013. Konsep dan Makna Pembelajaran untuk Membantu Memecahkan Problematika Belajar dan Mengajar. Alfabeta. Bandung. 276 hlm. 
Dewi dan Muhiri. 2020. Profil Keterampilan Proses Sains Mahasiswa...

Sanjaya,W. 2013. Penelitian Pendidikan. Kencana. Jakarta, 314 hlm.

Sugiyono. 2015. Metode Penelitian Kuantitatif dan R \&D. Alfabeta. Bandung, 456 hlm.

Trianto. 2012. Model Pembelajaran Terpadu : Konsep, Strategi, dan Implementasinya dalam Kurikulum Tingkat Satuan Pendidikan (KTSP). Bumi Aksara. Jakarta. 290 hlm.

Ulum, C. 2018. Keterampilan Sosial Peserta Didik dalam Pembelajaran Tematik di Kelas V MI Muhammadiyah Selo Kulon Pogo. Al-Bidayah: Jurnal Pendidikan Dasar Islam, 10(2): 229-253.

Utama, M.N., Ramadhani, R., Rohmani, S. N., dan Prayitno, B.A. 2019. Profil Keterampilan Literasi Sains Siswa di Salah Satu Sekolah Menengah Atas (SMA) Negeri di Surakarta. Didaktika Biologi, 3(2):57-67.

Wahyuni, N.D. 2013. Penerapan Metode Inkuiri untuk Meningkatkan Hasil Belajar Siswa pada Pembelajaran IPA di Sekolah Dasar. (Skripsi). Prodi PGSD FKIP Universitas Pendidikan Indonesia. Bandung.

Widodo, H. 2015. Potret Pendidikan di Indonesia dan Kesiapannya dalam Menghadapi Masyarakat Ekonomi Asia (MEA). Cendikia, 13(2): 293-307.

\begin{abstract}
Authors:
Tisrin Maulina Dewi, Program Studi PGSD, Fakultas Keguruan dan Ilmu Pendidikan, Universitas Karimun, Jl. Canggai Puteri Kec. Tebing Karimun, 29661, Kepulauan Riau, Indonesia, email: tisrinmaulinadewi@gmail.com Muhiri, Program Studi Penjaskesrek, Fakultas Keguruan dan Ilmu Pendidikan, Universitas Karimun, Jl. Canggai Puteri Kec. Tebing Karimun, 29661, Kepulauan Riau, Indonesia, email: hery080190@gmail.com

This is an open-access article distributed under the terms of the Creative Commons Attribution License, which permits unrestricted use, distribution and reproduction in any medium, provided the original author and source are credited. (http://creativecommons.org/licenses/by/4.0/).
\end{abstract}

\title{
How to cite this article:
}

Dewi, T. M., and Muhiri. 2020. Profile of science process skill elementary school college Students on biology concept course. Simbiosa, 9(2): 150-157. Doi. http://dx.doi.org/10.33373/sim-bio.v9i2.2602 